\title{
Development and evaluation of potential functional food biscuits made from White Lupin
}

\author{
CSABA CSUTORAS* (D, LEVENTE GIRAN, ORSOLYA HUDAK and \\ LASZLO RACZ
}

Department of Food Science, Eszterhazy Karoly Catholic University, Eszterhazy Sqr. 1, H-3300, Eger, Hungary

\section{ORIGINAL RESEARCH PAPER}

Received: October 15, 2021 • Accepted: November 8, 2021

Published online: November 25, 2021

(C) 2021 The Author(s)

\section{ABSTRACT}

Potential functional food bakery products were developed and characterized based on White Lupin (Lupinus albus cv. Nelly) flour. Analytical properties of the seeds resemble to previously described Lupinus species, with significantly high protein content (45\%). The high protein and dietetic fiber content of the seeds makes Lupin flour suitable to develop potential functional food products with high nutritional values. Results of the development of sweet biscuits and salty crackers enriched with Lupin flour are presented. Sensory evaluation of the bakery products was carried out by 15 panelists using the nine points hedonic scale. Heat stability of White Lupin proteins were investigated by gel-electrophoretic analysis, White Lupin proteins are quite stable at $140^{\circ} \mathrm{C}$, after $35 \mathrm{~min}$ heating the biscuits still contain $69 \%$ of the original amount of proteins. Baking conditions were optimized also based on gel-electrophoretic experiments, the optimal baking time was $30 \mathrm{~min}$ at $140^{\circ} \mathrm{C}$. Gluten-free Lupin-based biscuits and crackers were produced by completely omitting wheat flour from the recipes.

\section{KEYWORDS}

White Lupin, functional food, gluten-free, gel electrophoresis

\footnotetext{
*Corresponding author. E-mail: csutoras.csaba@uni-eszterhazy.hu
} 


\section{INTRODUCTION}

Grain legume seeds can be used for human and animal consumption or for the production of oils for industrial uses. Beans, lentils, lupins, peas, and peanuts are grain legumes (Hall et al., 2017). Legume seeds provide valuable proteins, therefore they have importance in human, as well as in vegan nutrition (Krintiras et al., 2016). Legume proteins contain high amount of lysine but only low amount of sulfur-containing amino acids. However, cereal proteins contain low amount of lysine, but appropriate amounts of sulfur-containing amino acids (Patil et al., 2016; Eggum and Beame, 1983). Using legume proteins in bakery products is therefore a possible way to improve the amino acid composition of the products. Soybean protein preparations (Bashir et al., 2015; Ribotta et al., 2005), chickpea flour (Gómez et al., 2008), germinated chickpea flour (da Costa et al., 2020; Fernandez and Berry, 1989), germinated pea flour (Bashir et al., 2015; Sadowska et al., 2003) as well as Lupin flour (Villarino et al., 2016; Pollard et al., 2002; Doxastakis et al., 2002; Dervas et al., 1999) were applied for the preparation of different bakery products. Lupin is a protein containing foods, like peanut and soybean, that may trigger an allergic reaction in a small percentage of the population. Some people who are allergic to peanuts may also react to lupin (Villa et al., 2020).

The genus Lupinus comprises above 200 species, but only a few species have become domesticated and cultivated on a large scale. Lupin is an economically and agriculturally valuable plant which can be grown in different soils even at cooler climates compared with soy. Lupin has a strong capability for fixation and organic phosphorus release from soil and can be used in crop rotation during intensive grain production (Duranti et al., 2008; Fan et al., 2002; Honeycutt, 1998).

Lupin is a grain legume with high protein content (more than $35 \mathrm{~m} \mathrm{~m}^{-1} \%$ ) and low oil content, similarly to soybean (Lucas et al., 2015; Sujak et al., 2006). Its amin advantage compared with other legumes is the low amount of anti-nutritional components (alkaloids, phytate) (Getachew et al., 2012) and lupin seeds lack other common anti-nutritional factors such as lectins and protease inhibitors (Lilley, 1999). Lupin is a good source of nutrients, not only proteins but lipids, dietary fiber, minerals and vitamins (Van de Noort, 2017; Martinez-Villaluenga et al., 2006; Torres et al., 2005; Petterson, 1998). Furthermore, Lupin contains phytochemicals with antioxidant capacity, such as polyphenols, mainly tannins and flavonoids (Król et al., 2018; Oomah et al., 2006). This legume has considerable cholesterol and glucose-lowering capacities (Ward et al., 2020; Duranti et al., 2008; Doxastakis et al., 2007; Makri et al., 2005; Mavrakis et al., 2003). Its proteins are mainly globulins that represent about $90 \%$ of the total protein content (Czubinski and Feder, 2019; Nadal et al., 2011). The utilization of Lupin can be extended to the production of protein concentrates, that can be promising food additives with their enriched nutritional value for the development of potential functional foods (Arnoldi et al., 2015; Archer et al., 2004; Dijkstra et al., 2003; Linnemann and Dijkstra, 2002; Marrs, 1996; Batterham et al., 1986). Effort to obtain Lupin protein concentrates containing $60-70 \%$ crude protein has been made by many research groups (Vogelsang-O'Dwyer et al., 2020; Chapleau and Lamballerie-Anton, 2003; Mubarak, 2001; Wasche et al., 2001). Protein concentrates can be used as a substance for enriching different kinds of products, such as pastries, breads, and milk.

Lupin proteins are gluten-free, therefore this legume can be suitable for the development of gluten-free food products, that can be consumed by people having wheat allergies, coeliac disease (CD) or other gluten related disorder (Taraghikhah et al., 2020). Food products may 
bear the term gluten-free if the gluten content does not exceed $20 \mathrm{mg} \mathrm{kg}^{-1}$, between 20 and $100 \mathrm{mg} \mathrm{kg}^{-1}$ gluten-content they should bear the term "very low gluten" according to the EC Regulation (Commission Regulation (EC), 2009). Gluten is the scientific name for the CDactivating proteins in wheat, it is composed of 2 main protein fractions: gliadins and glutenins (Capriles and Areas, 2014). In this paper we report on the development of wheat-based and gluten free biscuits and crackers based on white Lupin flour available in Europe.

\section{MATERIALS AND METHODS}

\section{Raw materials}

White Lupin (Lupinus albus cv. Nelly) was purchased from The Center for Agricultural and Applied Economic Sciences of University of Debrecen. Seeds were ground fine in a domestic mill (Widu 1, Germany), and the flour was filtered with $0.4 \mathrm{~mm}$ filter. White Lupin flour was added in different ratio to wheat flour. Corn starch was ordered from National Starch (BAKA SNAK E type) and gluten was provided by DETK biscuit manufacturer (Hungary). All other components (wheat flour (BL-55), sugar, salt, tartaric acid, etc.) are commercially available ingredients (Table 1).

\section{Chemical analysis}

Nitrogen content was determined by using the Kjeldahl method and was multiplied by a factor of 5.7 to determine protein content in lupin seeds (Hudson et al., 1976). Moisture content was determined by heating samples at $105^{\circ} \mathrm{C}$ to constant weight. Fat, moisture, protein and vitamin B content was expressed on a dry weight basis.

\section{Fat and fatty acid analysis}

Full fat white Lupin flour ( $5 \mathrm{~g}$ ) was suspended in $30 \mathrm{~mL}$ hexane. The suspension was sonicated for $25 \mathrm{~min}$ at room temperature, then centrifuged at $4,000 \mathrm{~g}$ for $20 \mathrm{~min}$. The extraction was repeated 2 more times with $30-30 \mathrm{~mL}$ hexane. The hexane solutions were evaporated to dryness by rotary evaporator. The aliquot $(1 \mathrm{~mL})$ was dissolved in isooctane, and ester derivative was prepared with $2 \mathrm{M} \mathrm{KOH}$ in methanol and neutralized with $\mathrm{NaHSO}_{4}$. The analysis of fatty acid methyl-esters were performed by GC-MS (Shimadzu, 2010; Supleco-wax column). FAME-mix and Grain-mix standards were used (Sigma-Aldrich). The analyses were repeated 3 times with different white lupin seed samples, the results are the average of 3 runs (Table 2).

Table 1. Source of raw materials

\begin{tabular}{ll}
\hline Material & \multicolumn{1}{c}{ Source } \\
\hline White Lupin & $\begin{array}{c}\text { The Center for Agricultural and Applied Economic Sciences of } \\
\text { University of Debrecen } \\
\text { National Starch }\end{array}$ \\
$\begin{array}{ll}\text { Corn starch } \\
\text { gluten }\end{array}$ & $\begin{array}{l}\text { DETK biscuit manufacturer (Hungary) } \\
\text { All other components (wheat flour } \\
\text { (BL-55), sugar, salt, tartaric acid, etc.) }\end{array}$ \\
\hline
\end{tabular}


Table 2. Fatty acids in Lupinus albus cv. Nelly

\begin{tabular}{lcr}
\hline Fatty acid & Tr $(\mathrm{min})$ & $\%$ \\
\hline myristic acid & 12 & 0.26 \\
palmitic acid & 16.3 & 16.79 \\
palmitoleic acid & 17.1 & 0.38 \\
cis-10-heptadecenoic acid & 20.7 & 2.06 \\
stearic acid & 24.2 & 42.54 \\
oleic acid & 25.3 & 1.8 \\
linoleic acid & 28 & 10.15 \\
linolenic acid & 32.7 & 8.43 \\
arachidic acid & 39.5 & 6.9 \\
cis-11-eicosenoic acid & 41.2 & 3.44 \\
behenic acid & 52.4 & 6.6 \\
erucic acid & 53.7 & 0.65 \\
\hline
\end{tabular}

${ }^{\star}$ Composition of Lupin seed oil: Saturated (73.09\%), Unsaturated (26.91\%), n-3 (8.43\%), n-6 (10.15\%), n-3/ n-6 (0.83).

\section{Determination of vitamins $B_{1}, B_{2}, B_{3}, B_{6}, B_{12}$ (Antakli et al., 2015)}

Lupin flour $(1 \mathrm{~mL})$ was mixed with $4 \mathrm{~mL}$-hexane and $16 \mathrm{~mL}$ HPLC grade water. The mixture was vigorously stirred for $30 \mathrm{~min}$ and was centrifuged at $4,000 \mathrm{~g}$ for $20 \mathrm{~min}$. Water phase was separated and filtered with $0.45 \mu \mathrm{m}$ membrane filter. The sample $(20 \mu \mathrm{L})$ was measured by HPLC-UV at $254 \mathrm{~nm}$. Column: C18 BDS $(100 \times 4.6 \mathrm{~mm} ; 3 \mu \mathrm{m})$; mobile phase: solvent (A): $5.84 \mathrm{mM}$ of hexane-1-sulfonic acid sodium:acetonitrile (95:5) with $0.1 \%$ triethylamine at $\mathrm{pH} 2.5$ and solvent (B): $5.84 \mathrm{mM}$ of hexane-1-sulfonic acid sodium:acetonitrile (50:50) with $0.1 \%$ triethylamine at $\mathrm{pH} 2.5$; flow rate: $1.6 \mathrm{~mL} \mathrm{~min}^{-1}$; column temperature: $40^{\circ} \mathrm{C}$.

\section{Preparation of white lupin total protein extract (Sironi et al., 2005)}

Lupin protein isolate (LPI) was prepared by alkaline water extraction and isoelectric precipitation. Lupin flour (10 g) (L. albus) was suspended in $100 \mathrm{~mL}$ of distilled water then $\mathrm{pH}$ was adjusted to 9.0 using $1 \mathrm{M} \mathrm{NaOH}$. The suspension was stirred for $1 \mathrm{~h}$ at room temperature, then centrifuged at $8,000 \mathrm{~g}$ for $20 \mathrm{~min}$. Extraction and centrifugation were repeated 2 more times. The extracts were combined and cooled to $4^{\circ} \mathrm{C}$ and acidified to $\mathrm{pH} 4.5$ using $1 \mathrm{M} \mathrm{HCl}$. The precipitate was recovered by centrifugation at $4^{\circ} \mathrm{C}$ at $8,000 \mathrm{~g}$ for $20 \mathrm{~min}$, then neutralized with $1 \mathrm{M}$ $\mathrm{NaOH}$ to $\mathrm{pH} 7.0$ and washed with distilled water 3 times. Then the neutralized precipitate was freeze-dried.

\section{Sodium dodecyl sulfate-polyacrylamide gel electrophoresis (SDS-PAGE)}

White Lupin protein isolates and biscuits were electrophoresed under reducing conditions, using a vertical gel electrophoresis apparatus (Cleaver Scientific, Omni Page mini). The Gels consisted of $5 \%$ stacking and $12 \%$ separating polyacrylamide gels and were electrophoresed at $10 \mathrm{~mA}$ current at stacking gel and $20 \mathrm{~mA}$ current at separating gel for 2.5-3 h. Gels were fixed with trichloroacetic acid (TCA) $(12 \mathrm{v} / \mathrm{v})$ and then treated with PAGE washing solution (water:ethanol:acetic acid 75:10:5 v/v/v). The gels were stained with Coomassie blue PAGE staining 
solutions (Fermentas) for $1 \mathrm{~h}$ and washed with water. Gel photos were made with a Biodoc apparatus (BioDoc-It-TM Imaging System) and were analyzed with Biodoc software (Doc-It-LS Image Analysis Software). Protein band volumes were determined by summarizing the grey values of the pixels and were corrected with the background.

\section{Heat stability of white lupin proteins during baking and optimizing baking conditions}

Baking parameters were optimized according to the data of heat stability of White Lupin proteins (Table 3). Lupin biscuits were made from full fat white lupin flour, corn starch and water. Batches were baked in an oven at $140^{\circ} \mathrm{C}$ for $20,25,30$ and $35 \mathrm{~min}$, at $150^{\circ} \mathrm{C}$ for $20,25,30$ and $35 \mathrm{~min}$, at $160^{\circ} \mathrm{C}$ for $20,25,30$ and $35 \mathrm{~min}$ and at $170^{\circ} \mathrm{C}$ for $20,25,30$ and $35 \mathrm{~min}$. Sample biscuits from each batch were pulverized in domestic grinder, added $(15 \mathrm{mg})$ to $1 \mathrm{~mL}$ sample buffer and were vortexed for $1 \mathrm{~h}$. Aliquots of the extracts were analyzed by SDS - PAGE. Gels were loaded with white lupin total protein extract, raw biscuit dough extract, biscuits and protein ladder (Fermentas, Pageruler, broad range, $5-250 \mathrm{kDa}$ ). The sample buffer consisted of $0.25 \mathrm{~mol} \mathrm{~L}^{-1}$ Tris- $\mathrm{HCl}, \mathrm{pH}$ 6.8, $7.5 \mathrm{~mL} / 100 \mathrm{~mL}$ glycerol, $20 \mathrm{mg} \mathrm{mL}^{-1} \mathrm{SDS}$ and $65 \mathrm{mmol} \mathrm{L}^{-1}$ 1,4-dithiothreitol (DTT). The intensity of protein bands was compared with the unbaked biscuit dough extract. To compare protein band intensities we selected distinguishable, well separated protein bands. The 44 and $47 \mathrm{kDa}$ sized double protein band is suitable for this purpose. The protein bands of baked biscuits were compared with bands of raw biscuit dough sample. Protein band volumes were determined by summarizing the grey values of the pixels of the protein band and were corrected with the background. Protein band volumes were determined with Biodoc software.

\section{Preparation and sensory evaluation of lupin biscuits}

For comparison purposes, lupin free biscuits and crackers were produced (Prokisch et al., 2017). The ingredients for reference sweet biscuits: $100 \mathrm{~g}$ wheat flour, $0.07 \mathrm{~g} \mathrm{NH}_{4} \mathrm{CO}_{3}, 0.63 \mathrm{~g} \mathrm{NaHCO}$, $0.06 \mathrm{~g}$ salt, $30 \mathrm{~g}$ sugar, $0.52 \mathrm{~g}$ tartaric acid, $2.19 \mathrm{~g}$ gluten, $10 \mathrm{~g}$ butter, $37.5 \mathrm{~mL}$ water. The ingredients for reference salty crackers: $100 \mathrm{~g}$ wheat flour, $10 \mathrm{~g}$ rice flour, $0.06 \mathrm{~g} \mathrm{NH}_{4} \mathrm{CO}_{3}, 0.6 \mathrm{~g}$ $\mathrm{NaHCO}_{3}, 4 \mathrm{~g}$ salt, $0.4 \mathrm{~g}$ sugar, $0.5 \mathrm{~g}$ tartaric acid, $2.5 \mathrm{~g}$ gluten, $20 \mathrm{~g}$ butter, $40 \mathrm{~mL}$ water (DETK Biscuit Manufacturer recipes). Gluten-free biscuits were prepared without using wheat flour and gluten in our recipes. In the case of gluten-free sweet Lupin biscuits instead of $100 \mathrm{~g}$ wheat flour Lupin flour and starch were used in different ratios, altogether $100 \mathrm{~g}$. In salty crackers $100 \mathrm{~g}$ Lupin flour and rice flour mixture was applied instead of wheat flour. Biscuits were evaluated by fifteen panelists with practice of sensory evaluation. Samples were rated on the nine points hedonic scale (Yu et al., 2007). Sensory scores: Like extremely $=9$, Like very much $=8$, Like moderately $=7$, Like slightly $=6$, Neither like nor dislike $=5$, Dislike slightly $=4$, Dislike moderately $=3$, Dislike very much $=2$, Dislike extremely $=1$.

Table 3. Relative protein band intensities (SDS-PAGE) during biscuit baking

\begin{tabular}{lcccc}
\hline Temperature $\left({ }^{\circ} \mathrm{C}\right)$ & $20 \mathrm{~min}$ & $25 \mathrm{~min}$ & $30 \mathrm{~min}$ & $35 \mathrm{~min}$ \\
\hline 140 & $99 \%$ & $99 \%$ & $99 \%$ & $69 \%$ \\
150 & $98 \%$ & $92 \%$ & $38 \%$ & $31 \%$. \\
160 & $85 \%$ & $53 \%$ & $33 \%$ & $11 \%$. \\
170 & $82 \%$ & n.d. & n.d. & n.d. \\
\hline
\end{tabular}




\section{RESULTS AND DISCUSSION}

\section{Composition of White Lupin seeds}

White Lupin "Nelly" seeds contain 12\% moisture, 45\% crude protein, $9 \%$ oil and 18\% fiber. White Lupin seeds did not contain vitamins $B_{1}$ and $B_{12}$, but vitamins $B_{2}, B_{3}$ and $B_{6}$ were detected in high amounts. In $100 \mathrm{~g}$ of White Lupin seed we found $3.46 \mathrm{mg}$ of $\mathrm{B}_{2}, 4.34 \mathrm{mg}$ of $\mathrm{B}_{3}$ and $1.18 \mathrm{mg}$ of $\mathrm{B}_{6}$ vitamins.

Table 2 shows that the fatty acid content of Lupin seed consists of $73 \%$ saturated fatty acids and $27 \%$ unsaturated fatty acids. The high content of oil in Lupin seeds, together with a high proportion of unsaturated fatty acids (Table 2) are desirable for human nutrition. The high amount of n-3 and n-6 fatty acids and their favorable ratio is prominent among other legumes (Jahreis et al., 2016).

The composition of fatty acids in White Lupin seed oil was determined by gas chromatography. Stearic acid (42.54\%) and palmitic acid (16.79\%) are the predominant fatty acids in Lupin seed oil, but among other fatty acids the saturated myristic acid $(12.0 \%)$ and the essential unsaturated linoleic (10.15\%) and linolenic acid $(8.43 \%)$ were in high percentage as well.

\section{Heat stability of White Lupin proteins}

White Lupin proteins are quite stable at $140^{\circ} \mathrm{C}$, after $35 \mathrm{~min}$ heating the biscuits still contain $69 \%$ of the original amount of proteins. After $25 \mathrm{~min}$ baking time at $150^{\circ} \mathrm{C}$ the intensity of the protein band drops significantly, after $30 \mathrm{~min}$ of baking over $60 \%$ of the proteins decomposed. At $160^{\circ} \mathrm{C}$, after 20 min baking time $15 \%$, after 25 min nearly half of the initial protein amount was decomposed. After $25 \mathrm{~min}$ baking time at $170^{\circ} \mathrm{C}$ there were no detectable protein bands. Based on these experimental data, the optimal baking time is $30 \mathrm{~min}$ at $140^{\circ} \mathrm{C}$ or $25 \mathrm{~min}$ at $150^{\circ} \mathrm{C}$. No new protein bands can be observed and all protein bands were fading equally. The relative protein band volumes are presented in Table 3.

\section{Sweet lupin biscuits}

The ratios of wheat flour, Lupin flour, gluten, starch and water were varied and the produced biscuits were evaluated in our experiments. The amount of wheat flour, Lupin flour and starch were always $100 \mathrm{~g}$. The compositions of sweet biscuits with their sensory scores are shown in Table 4.

Biscuits were baked at different temperatures. Applying $20 \mathrm{~min}$ baking time at $130^{\circ} \mathrm{C}$ (Batch 1) biscuits scored low on sensory evaluation, because of strong bitter Lupin flavor and pale color. The increase of baking temperature to $140^{\circ} \mathrm{C}$ resulted in weaker Lupin flavor (Batch 2 ), at $150^{\circ} \mathrm{C}$ the Lupin flavor completely disappeared (Batch 3). At this temperature most of the proteins are still intact, there is no Lupin bitter flavor and biscuits had pale yellow color, because of Maillard reaction. Batches $3-13$ were baked at $150^{\circ} \mathrm{C}$ for $25 \mathrm{~min}$. Increasing the ratio of Lupin flour, biscuits became slightly harder (Batches 4, 5 and 6). Batches 10-13 are vanilla flavored biscuits, which were produced by using $10 \mathrm{~g}$ of vanilla flavored sugar and $20 \mathrm{~g}$ sugar instead of $30 \mathrm{~g}$ sugar. Attempts were made to produce gluten free Lupin biscuits (Batches 
Table 4. Composition and sensory evaluation of sweet lupin biscuits

\begin{tabular}{|c|c|c|c|c|c|c|c|}
\hline $\begin{array}{l}\text { Batch } \\
\text { No. }\end{array}$ & $\begin{array}{l}\text { Wheat flour } \\
\text { (g) }\end{array}$ & $\begin{array}{l}\text { Lupin flour } \\
\text { (g) }\end{array}$ & $\begin{array}{l}\text { Corn starch } \\
\text { (g) }\end{array}$ & $\begin{array}{l}\text { Gluten } \\
\text { (g) }\end{array}$ & $\begin{array}{l}\text { Water } \\
(\mathrm{mL})\end{array}$ & Note & $\begin{array}{c}\text { Sensory } \\
\text { score }\end{array}$ \\
\hline Reference & 100 & - & - & 2.19 & 37.5 & $130^{\circ} \mathrm{C}$ & 7.8 \\
\hline 1 & 80 & 20 & - & 2.19 & 37.5 & $130^{\circ} \mathrm{C}$ & 5.2 \\
\hline 2 & 80 & 20 & - & 2.19 & 37.5 & $140^{\circ} \mathrm{C}$ & 5.9 \\
\hline 3 & 80 & 20 & - & 2.19 & 37.5 & & 7.1 \\
\hline 4 & 60 & 40 & - & 2.19 & 37.5 & & 7.3 \\
\hline 5 & 40 & 60 & - & 2.19 & 35 & & 6.3 \\
\hline 6 & 20 & 80 & - & 2.19 & 35 & & 5.1 \\
\hline 7 & - & 50 & 50 & - & 35 & & 5.5 \\
\hline 8 & - & 70 & 30 & - & 30 & & 5.3 \\
\hline 9 & - & 60 & 40 & - & 35 & & 5.6 \\
\hline 10 & 50 & 40 & 10 & 2.19 & 35 & $\begin{array}{l}\text { vanilla } \\
\text { flavored }\end{array}$ & 7.9 \\
\hline 11 & - & 50 & 50 & - & 35 & $\begin{array}{c}\text { vanilla } \\
\text { flavored }\end{array}$ & 6.4 \\
\hline 12 & - & 70 & 30 & - & 35 & $\begin{array}{l}\text { vanilla } \\
\text { flavored }\end{array}$ & 6.1 \\
\hline 13 & - & 60 & 40 & - & 35 & $\begin{array}{l}\text { vanilla } \\
\text { flavored }\end{array}$ & 7.1 \\
\hline
\end{tabular}

Ingredients not indicated: $0.07 \mathrm{~g} \mathrm{NH}_{4} \mathrm{CO}_{3}, 0.63 \mathrm{~g} \mathrm{NaHCO}_{3}, 0.06 \mathrm{~g}$ salt, $30 \mathrm{~g}$ sugar or $20 \mathrm{~g}$ sugar and $10 \mathrm{~g}$ vanilla sugar, $0.52 \mathrm{~g}$ tartaric acid, $10 \mathrm{~g}$ butter.

Note: Batches 7, 8, 9 and 11, 12, 13 are gluten-free.

7-9 and 11-13). The wheat flour was substituted with corn starch (National Starch, BAKA SNAK E type). The dough of biscuits made from Lupin flour and corn starch is thick and hard to handle, but after baking the products had acceptable texture and taste. Among Lupin enriched sweet biscuits Batch 4 and 10 scored the highest. The best score in the case of glutenfree Lupin biscuits was achieved in Batch 13, although it is slightly hard, its texture needs further development.

\section{Salty lupin crackers}

The ratios of wheat flour, Lupin flour, rice flour, gluten, corn starch and water were changed. The amount of wheat flour, Lupin flour, rice flour and corn starch were always $110 \mathrm{~g}$. The compositions of crackers are shown in Table 5. All salty crackers were baked at $150^{\circ} \mathrm{C}$ for $20 \mathrm{~min}$.

In the first nine crackers we omitted the rice flour completely. At low proportion of Lupin flour we experienced no changes in the texture and taste of crackers (Batches 1 and 2). At higher Lupin flour ratio, the crackers were slightly harder. By adding corn starch, rice flour or both to the dough, crackers became crunchier. Crackers with different wheat flour, Lupin flour, rice flour and corn starch ratios were produced. Best scoring products were Batch 10, 11 and 12. Among gluten-free crackers Batch 16 scored the highest on sensory evaluation. All these products were prepared from $40 \mathrm{~g}$ lupin flour. 
Table 5. Composition and sensory evaluation of salty lupin crackers

\begin{tabular}{lcccccccc}
\hline $\begin{array}{l}\text { Batch } \\
\text { No. }\end{array}$ & $\begin{array}{c}\text { Wheat } \\
\text { flour }(\mathrm{g})\end{array}$ & $\begin{array}{c}\text { Lupin } \\
\text { flour }(\mathrm{g})\end{array}$ & $\begin{array}{c}\text { Rice flour } \\
(\mathrm{g})\end{array}$ & $\begin{array}{c}\text { Corn } \\
\text { starch }(\mathrm{g})\end{array}$ & $\begin{array}{c}\text { Salt } \\
(\mathrm{g})\end{array}$ & $\begin{array}{c}\text { Gluten } \\
(\mathrm{g})\end{array}$ & $\begin{array}{c}\text { Water } \\
(\mathrm{mL})\end{array}$ & $\begin{array}{c}\text { Sensory } \\
\text { score }\end{array}$ \\
\hline Reference & 100 & - & 10 & - & 4 & 2.5 & 40 & 7.8 \\
1 & 100 & 10 & - & - & 4 & 2.5 & 40 & 7.2 \\
2 & 90 & 20 & - & - & 3.5 & 2.5 & 40 & 7.1 \\
3 & 70 & 40 & - & - & 3.5 & 2.5 & 40 & 6.6 \\
4 & 55 & 55 & - & - & 4 & 2.5 & 40 & 5.5 \\
5 & - & 55 & - & 55 & 4 & - & 40 & 5.5 \\
6 & - & 70 & - & 40 & 4 & - & 40 & 5.2 \\
7 & 70 & 30 & - & 10 & 4 & 2.5 & 40 & 7.0 \\
8 & 55 & 55 & - & - & 3.5 & 2.5 & 40 & 6.3 \\
9 & 60 & 40 & - & 10 & 3.5 & 2.5 & 40 & 6.9 \\
10 & 50 & 40 & 10 & 10 & 3.5 & 2.5 & 40 & 7.7 \\
11 & 50 & 40 & - & 20 & 4 & 2.5 & 40 & 7.6 \\
12 & 55 & 40 & - & 15 & 4 & 2.5 & 40 & 7.6 \\
13 & 45 & 35 & - & 30 & 4 & 2.5 & 43 & 6.5 \\
14 & 60 & 40 & 10 & - & 4 & 2.5 & 42 & 7.3 \\
15 & - & 40 & 30 & 40 & 4 & - & 40 & 6.5 \\
16 & - & 40 & 30 & 40 & 4 & - & 45 & 7.1 \\
\hline
\end{tabular}

Ingredients not indicated: $0.06 \mathrm{~g} \mathrm{NH}_{4} \mathrm{CO}_{3}, 0.6 \mathrm{~g} \mathrm{NaHCO}, 0.4 \mathrm{~g}$ sugar, $0.5 \mathrm{~g}$ tartaric acid, $20 \mathrm{~g}$ butter. Note: Batches 5, 6 and 15, 16 are gluten-free.

\section{CONCLUSIONS}

Full fat White Lupin flour is a good source of nutrients; it has high protein content and good amino acid composition. Lupin seeds do not contain gluten proteins that makes Lupin flour a feasible ingredient to make gluten-free products. In this paper we showed that full fat White Lupin flour is suitable to produce gluten-free sweet biscuits and salty crackers with good sensory evaluation values, acceptable texture and taste. Although these products are slightly harder compared to the corresponding wheat flour products, further developments can result in new Lupin-based gluten-free products.

\section{ACKNOWLEDGEMENT}

This work was supported by a KFI-2020-1.1.2. Grant of the Hungarian Government.

\section{REFERENCES}

Arnoldi, A., Boschin, G., Zanoni, C., and Lammi, C. (2015). The health benefits of sweet lupin seed flours and isolated proteins. Journal of Functional Foods, 18: 550-563, https://doi.org/10.1016/j.jff.2015.08.012. 
Antakli, S., Sarkees, N., and Sarraf, T. (2015). Determination of water-soluble vitamins B1, B2, B3, B6, B9, B12 and $\mathrm{C}$ on $\mathrm{C} 18$ column with particle size $3 \mu \mathrm{M}$ in some manufactured food products by HPLC with UVDAD/FLD detection. International Journal of Pharmacy and Pharmaceutical Sciences, 7(6): 219-224.

Archer, B. J., Johnson, S. K., Devereux, H. M., and Baxter, A. L. (2004). Effect of fat replacement by inulin or lupin-kernel fibre on sausage patty acceptability, post-meal perceptions of satiety and food intake in men. The British Journal of Nutrition, 91(4): 591-599. https://doi.org/10.1079/BJN20031088.

Bashir, A., Ashraf, S. A., Khan, M. A., and Azaz Ahmad Azad, Z. R. (2015). Development and compositional analysis of protein enriched soybean-pea-wheat flour blended cookies. Asia Pacific Journal of Clinical Nutrition, 7(3): 76-83. https://doi.org/10.3923/ajcn.2015.76.83.

Batterham, E. S., Andersen, L. M., Lowe, R. F., and Darnell, R. E. (1986). Nutritional value of lupin (Lupinus albus)-seed meal for growing pigs: availability of lysine, effect of autoclaving and net energy content. The British Journal of Nutrition, 56(3): 645-659. https://doi.org/10.1079/BJN19860145.

Capriles, V. D., and Areas, J. A. G. (2014). Novel approaches in gluten-free breadmaking: interface between food science, nutrition, and health. Comprehensive Reviews in Food Science and Food Safety, 13: 871890, https://doi.org/10.1111/1541-4337.12091.

Chapleau, N., and Lamballerie-Anton, M. (2003). Improvement of emulsifying properties of lupin proteins by high pressure induced aggregation. Food Hydrocolloids, 17: 273-280, https://doi.org/10.1016/S0268005X(02)00077-2.

Yu, J., Ahmedna, M., and Goktepe, I. (2007). Peanut protein concentrates: production and functional properties as affected by processing. Food Chemistry, 103(1): 121-129, https://doi.org/10.1016/j. foodchem.2006.08.012.

Commission Regulation (EC) No. 41/2009 concerning the composition and labelling of foodstuffs suitable for people intolerant to gluten. European Union Legislation, FAO, FAOLEX, Available at: http:// extwprlegs1.fao.org/docs/pdf/eur84558.pdf.

Czubinski, J. and Feder, S. (2019). Lupin seeds storage protein composition and their interactions with native flavonoids. Journal of the Science of Food and Agriculture, 99: 4011-4018. https://doi.org/10. 1002/jsfa.9627.

da Costa, R. T., da Silva, S. C., Silva, L. S., da Silva, W. A., Goncalves, A. C. A., Pires, C. V., Martins, A. M. D., Chávez, D. W. H., and Trombete, F. M. (2020). Whole chickpea flour as an ingredient for improving the nutritional quality of sandwich bread: effects on sensory acceptance, texture profile, and technological properties. Revista chilena de nutrición, 47(6): 933-940, http://dx.doi.org/10.4067/S071775182020000600933.

Dervas, G., Doxastakis, G., Hadjisavva-Zinoviadi, S., and Triantafillakos, N. (1999). Lupine flour addition to wheat flour dough and effect on rheological properties. Food Chemistry, 66: 67-73, https://doi.org/10. 1016/S0308-8146(98)00234-9.

Dijkstra, D. S., Linnemann, A. R., and van Boekel, T. A. (2003). Towards sustainable production of proteinrich foods: appraisal of eight crops for Western Europe PART II: analysis of the technological aspects of the production chain. Critical Reviews in Food Science and Nutrition, 43(5): 481-506. https://doi.org/10. 1080/10408690390246332.

Doxastakis, G., Papageorgiou, M., Mandalou, D., Irakli, M., Papalamprou, E., D’Agostina, A., Resta, D., Boschin, G., and Arnoldiet, A. (2007). Technological properties and non-enzymatic browning of white lupin protein enriched spaghetti. Food Chemistry, 101: 57-64, https://doi.org/10.1016/j.foodchem.2005.12.054.

Doxastakis, G., Zafiriadis, I., Irakli, M., and Tananaki, C. (2002). Lupin, soya and triticale addition to wheat flour doughs and their effect on rheological properties. Food Chemistry, 77: 219-227, https://doi.org/10. 1016/S0308-8146(01)00362-4. 
Duranti, M., Consonni, A., Magni, C., Sessa, F., and Scafaroni, A. (2008). The major proteins of lupin seed: characterisation and molecular properties for use as functional and nutraceutical ingredients. Trends in Food Science \& Technology, 19: 624-633, https://doi.org/10.1016/j.tifs.2008.07.002.

Eggum, B. O. and Beame, R. M. (1983). The nutritive value of seed proteins. In: Gottschalk, W. and Muller, P. H. (Eds.), Seed protein biochemistry, genetics and nutritive value. Junk, The Hague, pp 499-531. https://doi.org/10.1007/978-94-009-6801-1.

Fan, X. H., Tang, C., and Rengel, Z. (2002). Nitrate uptake, nitrate reductase distribution and their relation to proton release in five modulated grain legumes. Annals of Botany, 90(3): 315-323. https://doi.org/10. 1093/aob/mcf190.

Fernandez, M. L., and Berry, J. W. (1989). Rheological properties of flour and sensory characteristics of bread made from germinated chickpea. International Journal of Food Science, 24: 103-110, https://doi. org/10.1111/j.1365-2621.1989.tb00623.x.

Getachew, P., Umeta, M., Retta, N., Bekele, T., and Desse Haki, G. (2012). Proximate composition and anti-nutritional factors of traditionally processed white lupine (Lupinus Albus L.) Fabaceae, grown in Ethiopia. Ethiopian Journal of Biological Sciences, 11(2): 133-146, https://doi.org/10.4314/EJBS. V112.

Gómez, M., Oliete, B., Rosell, C. M., Pando, V., and Fernández, E. (2008). Studies on cake quality made of wheat-chickpea flour blends. LWT - Food Science and Technology, 41: 1701-1709, https://doi.org/10. 1016/j.lwt.2007.11.024.

Hall, C., Hillen, C., and Garden Robinson, J. (2017). Composition, nutritional value, and health benefits of pulses. Cereal Chemistry, 94(1): 11-31, https://doi.org/10.1094/CCHEM-03-16-0069-FI.

Honeycutt, C. W. (1998). Crop rotation impacts on potato protein. Plant Foods for Human Nutrition, 52(4): 279-291. https://doi.org/10.1023/A:1008046223958.

Hudson, B. J. T., Fleetwood, J. G., and Zand-Moghaddam, A. (1976). Lupine an arable food crop for temperate climate. Plant Foods for Human Nutrition, 2: 81-83. https://doi.org/10.1080/03062686.1976. 11904186.

Jahreis, G., Brese, M., Leiterer, M., Schäfer, U., and Böhm, V. (2016). Legume flours: Nutritionally important sources of protein and dietary fiber. Ernahrungs Umschau, 63: 36-42, https://doi.org/10. 4455/eu.2016.007.

Krintiras, G. A., Gadea Diaz, J., van der Goot, A. J., Stankiewicz, A. I., and Stefanidis, G. D. (2016). On the use of the Couette Cell technology for large scale production of textured soy-based meat replacers. Journal of Food Engineering, 169: 205-213, https://doi.org/10.1016/j.jfoodeng.2015.08.021.

Król, A., Amarowicz, R., and Weidner, S. (2018). Content of phenolic compounds and antioxidant properties in seeds of sweet and bitter cultivars of lupine (Lupinus angustifolius). Natural Product Communications, 13(10): 1341-1344. https://doi.org/10.1177/1934578X1801301027.

Lilley, G. G. (1999). Lupin globulins. In: Shewry, P. R. and Casey, R. (Eds.), Seed proteins. Springer, Dordrecht. https://doi.org/10.1007/978-94-011-4431-5_14.

Linnemann, A. R. and Dijkstra, D. S. (2002). Toward sustainable production of protein-rich foods: appraisal of eight crops for Western Europe. Part I. Analysis of the primary links of the production chain. Critical Reviews in Food Science and Nutrition, 42(4): 377-401. https://doi.org/10.1080/ 20024091054193.

Lucas, M. M., Stoddard, F. L., Annicchiarico, P., Frias, J., Martínez-Villaluenga, C., Sussmann, D., Duranti, M., Seger, A., Zander, P. M., and Pueyo, J. J. (2015). The future of lupin as a protein crop in Europe. Frontiers in Plant Science, 6: 705, https://doi.org/10.3389/fpls.2015.00705. 
Makri, E., Papalamprou, E., and Doxastakis, G. (2005). Study of functional properties of seed storage proteins from indigenous European legume crops (lupin, pea, broad bean) in admixture with polysaccharides. Food Hydrocolloids, 19: 583-594, https://doi.org/10.1016/j.foodhyd.2004.10.028.

Marrs, T. (1996). Lupin based food. Health Bulletin (Edinb.), 54(5): 366-367.

Martínez-Villaluenga, C., Frías, J., and Vidal-Valverde, C. (2006). Functional lupin seeds (Lupinus albus and Lupinus luteus) after extraction of $\alpha$-galactosides. Food Chemistry, 98: 291-299, https://doi.org/10. 1016/j.foodchem.2005.05.074.

Mavrakis, C., Doxastakis, G., and Kiosseoglou, V. (2003). Large deformation properties of gels and model comminuted meat products containing lupin protein. Journal of Food Science, 68: 1371-1376. https:// doi.org/10.1111/j.1365-2621.2003.tb09652.x.

Mubarak, A. E. (2001). Chemical, nutritional and sensory properties of bread supplemented with lupin seed (Lupinus albus) products. Nahrung, 45(4): 241-245. https://doi.org/10.1002/1521-3803(20010801)45: 4<241::AID-FOOD241>3.0.CO;2-Z.

Nadal, P., Canela, N., Katakis, I., and O'Sullivan, C. K. (2011). Extraction, isolation, and characterization of globulin proteins from Lupinus albus. Journal of Agricultural and Food Chemistry, 59(6): 2752-2758, https://doi.org/10.1021/jf104062d.

Oomah, B. D., Tiger, N., Olson, M., and Balasubramanian, P. (2006). Phenolics and antioxidative activities in narrow-leafed lupins (Lupinus angustifolius L.). Plant Foods for Human Nutrition, 61: 91-97. https:// doi.org/10.1007/s11130-006-0021-9.

Patil, S. S., Brennan, M. A., Mason, S. L., and Brennan, C. S. (2016). The effects of fortification of legumes and extrusion 3 on the protein digestibility of wheat-based snack. Foods, 5(2): 26. https://doi.org/10. 3390/foods5020026.

Petterson, D. S. (1998). Composition and food uses of lupin. In: Gladstones, J. S., Atkins, C. A., and Hamblin, J. (Eds.), Lupinus as crop plants: biology, production and utilization. CAB International, Wallinford, Oxon, pp. 353-384. ISBN 0851992242.

Pollard, N. J., Stoddard, F. L., Popineau, Y., Wrigley, C. W., and MacRitchie, F. (2002). Lupin flours as additives: dough mixing, breadmaking, emulsifying, and foaming. Cereal Chemistry, 79: 662-669, https://doi.org/10.1094/CCHEM.2002.79.5.662.

Prokisch, J., Csiki, Z., Albert, C., and Csapó, J. (2017). Production of high-lysine-content biscuit and examination of the absorption of lysine in humans. Acta Universitatis Sapientiae, Alimentaria, 10(1): 2135, https://doi.org/10.1515/ausal-2017-0002.

Ribotta, P. D., Arnulphi, S. A., León, A. E., and Anón, M. C. (2005). Effect of soybean addition on the rheological properties and breadmaking quality of wheat flour. Journal of the Science of Food and Agriculture, 85: 1889-1896. https://doi.org/10.1002/jsfa.2191.

Sadowska, J., Blaszczak, W., Fornal, J., Vidal-Valverde, C., and Frias, J. (2003). Changes of wheat dough and bread quality and structure as a result of germinated pea flour addition. European Food Research and Technology, 216: 46-50, https://doi.org/10.1007/s00217-002-0617-8.

Sironi, E., Sessa, F., and Duranti, M. (2005). A simple procedure of lupin seed protein fractionation for selective food applications. European Food Research and Technology, 221: 145-150, https://doi.org/10. 1007/s00217-005-1151-2.

Sujak, A., Kotlarz, A., and Strobel, W. (2006). Compositional and nutritional evaluation of several lupin seeds. Food Chemistry, 98: 711-719, https://doi.org/10.1016/j.foodchem.2005.06.036.

Taraghikhah, N., Ashtari, S., and Asri, N. (2020). An updated overview of spectrum of gluten-related disorders: clinical and diagnostic aspects. BMC Gastroenterology, 20: 258. https://doi.org/10.1186/ s12876-020-01390-0. 
Torres, A., Frias, J., and Vidal-Valverde, C. (2005). Changes in chemical composition of lupin seeds (Lupinus angustifolius) after a-galactoside extraction. Journal of the Science of Food and Agriculture, 85: 2468-2474. https://doi.org/10.1002/jsfa.2278.

Van de Noort, M. (2017). Lupin: an important protein and nutrient source. In: Nadathur, S. R., Wanasundara, J. P. D., and Scanlin, L. (Eds.), Sustainable protein sources. Academic Press, pp. 165-183. ISBN: 9780128027783.

Villa, C., Costa, J., and Mafra, I. (2020). Lupine allergens: clinical relevance, molecular characterization, cross-reactivity, and detection strategies. Comprehensive Reviews in Food Science and Food Safety, 19: 3886-3915, https://doi.org/10.1111/1541-4337.12646.

Villarino, C. B. J., Jayasena, V., Coorey, R., Bell, S., and Johnson, S. K. (2016). Nutritional, health and technological functionality of lupin flour addition to bread and other baked products: benefits and challenges. Critical Reviews in Food Science and Nutrition, 56(5): 835-857. https://doi.org/10.1080/ 10408398.2013.814044.

Vogelsang-O’Dwyer, M., Bez, J., Petersen, I. L., Joehnke, M. S., Detzel, A., Busch, M., Krueger, M., Ispiryan, L., O’Mahony, J. A., Arendt, E. K., and Zannini, E. (2020). Techno-functional, nutritional and environmental performance of protein isolates from blue lupin and white lupin. Foods, 9: 230. https://doi. org/10.3390/foods 9020230 .

Ward, N. C., Mori, T. A., Beilin, L J., Johnson, S., Williams, C., Gan, S. K., Puddey, I. B., Woodman, R., Phillips, M., Connolly, E., and Hodgson, J. M. (2020). The effect of regular consumption of lupincontaining foods on glycaemic control and blood pressure in people with type 2 diabetes mellitus. Food and Function, 11(1): 741-747, https://doi.org/10.1039/C9FO01778J.

Wasche, A., Müller, K., and Knauf, U. (2001). New processing of lupin protein isolates and functional properties. Nahrung, 45(6): 393-395. https://doi.org/10.1002/1521-3803(20011001)45:6<393::AIDFOOD393>3.0.CO;2-O.

Open Access. This is an open-access article distributed under the terms of the Creative Commons Attribution 4.0 International License (https://creativecommons.org/licenses/by/4.0/), which permits unrestricted use, distribution, and reproduction in any medium, provided the original author and source are credited, a link to the CC License is provided, and changes - if any - are indicated. (SID_1) 